\title{
TRANSFORMING GROWTH FACTOR BETA OF TESTIS GERMINAL CELL IN GUINEA PIG (CAVIA PORCELLUS) AFTER EXPOSURE TO METHANOL EXTRACT OF THE SEEDS OF BITTER MELON (MOMORDICA CHARANTIA) AND DEPOT MEDROXYPROGESTERONE ACETATE
}

\author{
SYAFRUDDIN ILYAS ${ }^{1,2 *}$, SALOMO HUTAHAEAN ${ }^{1}$, NURSAL ${ }^{1}$ \\ ${ }^{1}$ Departement of Biology, Faculty of Mathematics and Natural Sciences, Universitas Sumatera Utara, Jl.Bioteknologi No. 1 Kampus USU, \\ Padang Bulan, Medan, Indonesia. ${ }^{2}$ Featured Center for Science and Technology “Stem Cell”, Universitas Sumatera Utara, Jalan Dr. Masyur \\ No. 4, Kampus USU Padang Bulan, Medan, Indonesia. *Email: syafruddin6@usu.ac.id
}

Received: 12 June 2018, Revised and Accepted: 23 July 2018

ABSTRACT

Objective: The discovery of male contraceptive drugs continues to be pursued, due to the very small participation of men associated with the lack of contraceptiveĐptions for men. The combination of methanol extract of bitter melon seed and depot medroxyprogesterone acetate (DMPA) becomes the choice that currently being pursued to be applied to men.

Methods: The use of guinea pigs as experimental animals conducted research using experimental methods with complete randomized design. The study was divided into four control groups i.e K0; dimethylsulfoxide (DMSO) for 0 week (4 h),K1; Control group of DMSO for 4 weeks, K2; Control group of DMSO for 8 weeks, K3; Control group of DMSO for 12 weeks, and four treatment groups, i.e: group P0; bitter melon seed extract of 50 $\mathrm{mg} / 100 \mathrm{~g}$ body weight/day for 0 week $(4 \mathrm{~h}$ ), group P1; Bitter melon seed extract of $50 \mathrm{mg} / 100 \mathrm{~g}$ BW/day for 4 weeks+DMPA, group P2; Bitter melon seed extract of $50 \mathrm{mg} / 100 \mathrm{~g}$ BW/day for 8 weeks+DMPA, P3 group; Bitter melon seed extract of $50 \mathrm{mg} / 100 \mathrm{~g}$ BW/day for 12 weeks+DMPA.

Results: There was a significant effect $(\mathrm{p}<0.05)$ methanol extract of bitter melon seed to increase the transforming growth factor expression $-\beta$ expression.

Conclusion: The methanol extract of bitter melon seed was able to be candidate for herbal contraception.

Keywords: Testis histology, MDA, Bitter melon, Guinea pig

(c) 2018 The Authors. Published by Innovare Academic Sciences Pvt Ltd. This is an open access article under the CC BY license (http://creativecommons. org/licenses/by/4. 0/) DOI: http://dx.doi.org/10.22159/ajpcr.2018.v11i12.27920

\section{INTRODUCTION}

According to the Survey of Indonesia Health Demographic at the 2002 , family planning participation is still very low, only $4.4 \%$, which include condom use $(0.9 \%)$, vasectomy/male surgery method $(0.4 \%)$, intermittent intercourse (1.5\%), and periodic abstinence $(1.6 \%)$ [1]. The participation rate as a family planning acceptor is still very low when compared with Islamic countries, such as Bangladesh at $13.9 \%$ in 1997 [2] and Malaysia at $16.8 \%$ in 1998 [3,4].

Male was less interested in becoming "family planning" acceptor because there were no many contraceptive options available [5-7]. Therefore, it is necessary to develop from herbs, one of the seeds of bitter melon (Momordica charantia) [5-18]. Combination of bitter melon seed with depot medroxyprogesterone acetate (DMPA) was better able to suppress spermatogenesis in mice $[19,20]$ and rabbits so as to decrease the quantity and quality [21]. The content of flavonoids in bitter melon seeds can lower serum testosterone levels so that it can cause decreased libido [22-24]. Therefore, DMPA should be added which is the source of testosterone in serum [1,19,20,25-31].

But in chemical compound in plant, Highly variable toxicities in plants and tissue sensitivity, depending upon the solvent used for extraction, the tool likes Column chromatography of the crude extracts lead to a number of fractions such as as potent anti cancer agents, scopoletin and $\beta$-sitosterol glucoside those have antioxidant property [127-130].

The workings of bitter melon seed extract and DMPA through hormonal mechanism of hypothalamus-pituitary-testis like assayed adrenocorticotropic hormone, cortisol and prolactin and activate of HPA axis [32-47]. Decreased intratesticular testosterone levels can cause disruption to spermatogenesis so that the resulting spermatozoa is reduced even cannot be produced. Testosterone may enter the seminiferous tubule and bind by androgen-binding protein (ABP) so that it can be used for the growth and development of spermatogonia as its stem cell spermatozoa [48-54]. Testosterone is required when spermatogonia are transformed into spermatocytes, spermatids, and spermatozoa in the seminiferous tubules $[34,44,55,56]$.

Transforming growth factor beta (TGF- $\beta$ ) is a protein secreted to regulate the proliferation, differentiation, and death of different cell types [57-66]. If linked to the research of bittter melon seed extract and DMPA, then there is no report that reveals in detail about TGF- $\beta$ picture in tubulus seminiferus after giving extract methanol bitter melon seed and DMPA. Therefore, this study is very important to explain the existence of TGF- $\beta$ in spermatogenesis in seminiferous tubules.

\section{METHODS}

The study subjects used healthy male healthy guinea pigs aged 8-11 months (proven to have once-a-year offspring when mated with a female guinea pig) weighing $400-450 \mathrm{~g}$ and placed in a clean cage. The study has received permission from the Research Ethics Committee of Health with no. 085/KEPH-FMIPA/2017.

\section{Measurement of phytochemistry}

Fenol test

Phenolic test was performed by reacting leaf ethanol extract and mulberry fruit (Morus alba L.) with $1 \% \mathrm{FeCl} 3$ solution. The results are shown by green, red, purple, dark blue, blue, blackish, or greenish-green. 
Flavonoid test

The flavonoid test was performed by heating the ethanol extract of leaves and mulberry fruit for $5 \mathrm{~min}$ and then adds a few drops of the concentrated $\mathrm{HCl}$ and $\mathrm{Mg}$ powder. The results are indicated by the appearance of dark red.

\section{Terpenoid}

The terpenoid test is performed by reacting leaf and fruit extracts of mulberry (M. alba L.) with $0.5 \mathrm{~mL}$ of ethanol, $0.5 \mathrm{~mL}$ of anhydrous acetic acid, and $2 \mathrm{~mL}$ of concentrated sulfuric acid through the tube wall. Results are indicated by the formation of green and blue (triterpenoid) and red or purple (steroid) [49,67-93].

Data were analyzed descriptively qualitative. The data obtained are primary data from a phytochemical screening of methanol extract of bitter melon seed in the laboratory of organic chemistry and natural materials of Chemistry Department of Faculty of Mathematics and Natural Sciences, Universitas Sumatera Utara.

\section{Immunohistochemistry of TGF- $\beta$ of guinea pig testis}

Testicular samples were taken from guinea pig by autopsy, then fixed with Bouin, end of fixation inserted in paraffin, and then cut with microtome with a thickness of $5 \mu \mathrm{m}$. Fixatives significantly improve the specificity and sensitivity of TGF- $\beta$ while maintaining morphology in storage [84,94]. For obseravtion of histology of testis cell each guinea pig \pm 10 field of view and calculated positive of TGF- $\beta$ in seminiferous tubules with calculation criteria such as Table 1.

\section{RESULTS}

Based on the research that has been done in Medan, the results obtainedĐn various parameters ie:

Phytochemical testing of simplicia and seed extract of bitter melon seed

From data collection, the result of phytochemical testing of simplicia and bitter melon seed extract is presented in Table 2.

Table 1: The scoring system used

\begin{tabular}{|c|c|c|}
\hline $\begin{array}{l}\text { Score the proportion } \\
\text { of staining }\end{array}$ & $\begin{array}{l}\text { Intensity of } \\
\text { nucleus staining }\end{array}$ & Added score \\
\hline $\begin{array}{l}0=\text { nucleus is not } \\
\text { colored }\end{array}$ & $0=$ no staining & $\begin{array}{l}0=\text { no treatment } \\
\text { response }\end{array}$ \\
\hline $\begin{array}{l}1=<1 \% \text { nucleus } \\
\text { colored }\end{array}$ & 1=weak staining & $\begin{array}{l}2-3=\text { small } \\
\text { treatment } \\
\text { response }(20 \%)\end{array}$ \\
\hline $\begin{array}{l}2=1-10 \% \text { nucleus } \\
\text { colored }\end{array}$ & $\begin{array}{l}2=\text { moderate } \\
\text { staining }\end{array}$ & $\begin{array}{l}4-6=\text { medium } \\
\text { treatment } \\
\text { response }(50 \%)\end{array}$ \\
\hline $\begin{array}{l}3=11-33 \% \text { nucleus } \\
\text { colored }\end{array}$ & $3=$ strong staining & $\begin{array}{l}7-8=\text { good } \\
\text { response } \\
\text { treatment }(75 \%)\end{array}$ \\
\hline $\begin{array}{l}4=34-66 \% \text { nucleus } \\
\text { colored } \\
5=67-100 \% \text { nucleus } \\
\text { colored }\end{array}$ & & \\
\hline
\end{tabular}

Table 2: Results of phytochemical testing of simplicia and bitter melon seed extract

\begin{tabular}{lll}
\hline Compound & Simplicia & Methanol extract \\
\hline Phenolic & - & - \\
Flavonoid & + & + \\
Terpenoid & + & + \\
\hline
\end{tabular}

Scanning electron microscope (SEM)

SEM extract methanol seeds of bitter melon done in Indonesian science institutions (LIPI), Cibinong (Fig. 1).

\section{DISCUSSIONS}

The concentration of guinea pig spermatozoa after giving of bitter melon seed extract is shown in Fig. 2. The administration of the methanol extract of bitter melon seed until weeks 12 and 16 was significantly different $(p<0.05)$ when compared between treatment and control. This suggests a good influence on suppressing spermatozoa concentrations produced by guinea pig of testicles. Spermatozoa concentration is highly determined on the process of spermatogenesis or stages of spermatozoa cell formation starting from spermatogonia, spermatocytes, and spermatids. Provision of bitter melon seed extract allows the decrease in testosterone levels in the testes (intratesticular testosterone) through repeated administration. Bitter melon seed extract contains $\beta$-Sitosterol with chemical structures similar to that of cholesterol. Cholesterol is a source of testosterone and enters the testicles so that the intratesticular testosterone is increased and consequently causes negative feedback to the hypothalamus and pituitary. The hypothalamus reduces the production of follicle-stimulating hormone-releasing hormone and luteinizing hormone-releasing hormone to affect the pituitary so that FHS and LH production is reduced [95-103]. The reduction of FSH affects Sertoli cells in producing $\mathrm{ABP}$ or testosterone receptors [104-110]. LH reduction suppresses Leydig cells to produce testosterone hormones [111-117]. These two ingredients are very important in the development and growth of spermatozoa cells so that production interruption will reduce the production of spermatozoa cells in the testes.

Beta-sitosterol D-glucoside is a phytosterol contained in M. charantia Linn. and several other plants [118-121]. Beta-sitosterol D-glucoside has many pharmacological activities [118-124] such as androgenic, antiadenomic, anticancer [129-134], antiedemic [135], and antiinflammatory [136-142]. Sitosterol has a structure such as cholesterol that later in the body can become the precursor of testosterone and

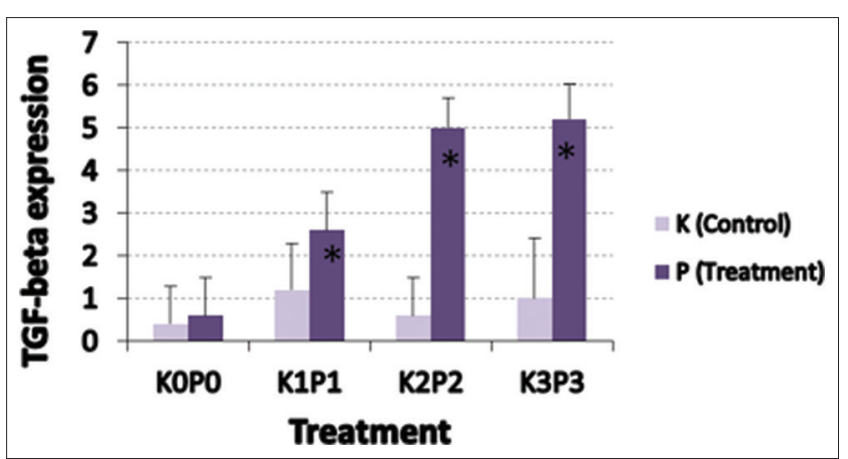

Fig. 1: Bar graphic of transforming growth factor beta of guinea pig. $\mathrm{p}^{*}<0.05=$ the same pair between control and treatment, $\mathrm{KOP0}=$ control and treatment on week-0, K1P1=control and treatment on the week 4, K2P2=control and treatment on the week 8, K3P3=control and treatment on the week 12

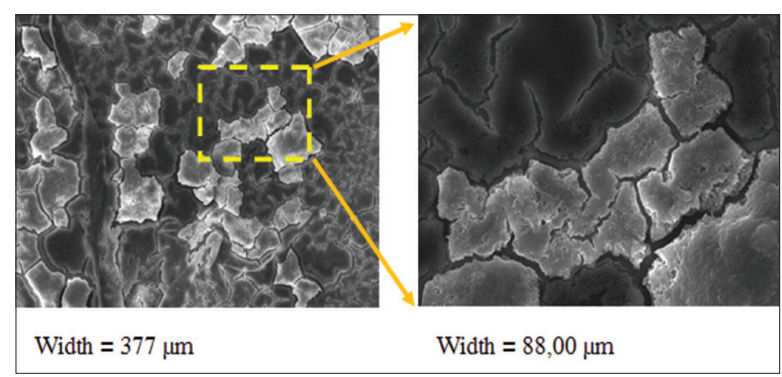

Fig. 2: Scanning electron microscope of extract methanol seeds of bitter lemon 

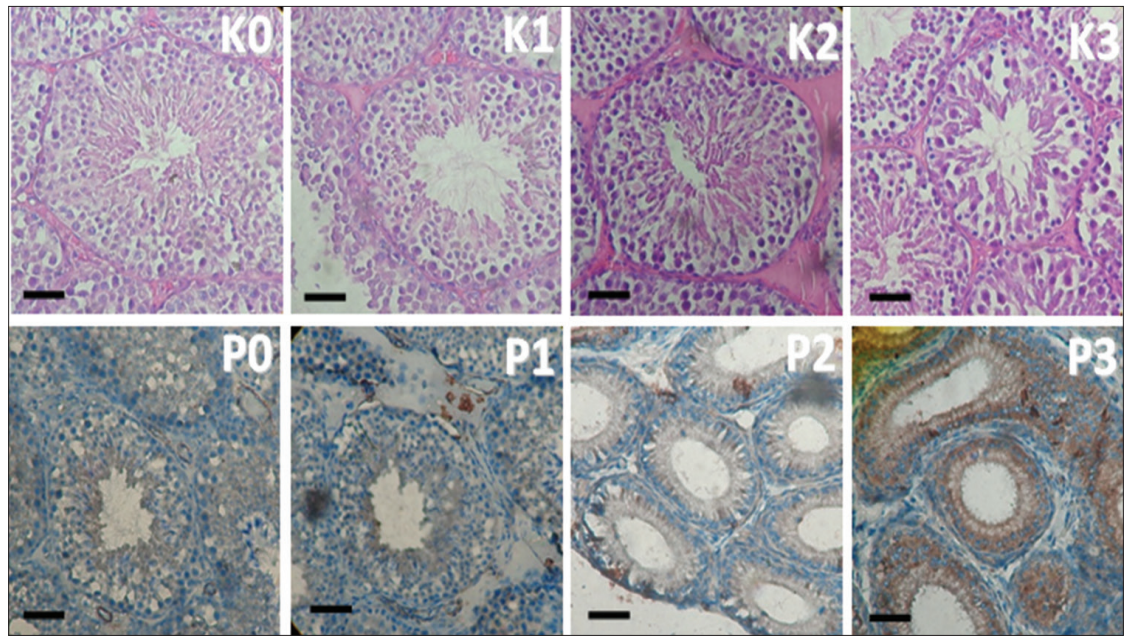

Fig. 3: Photomicrograph of seminiferous tubules in guinea pigs: $\mathrm{KOPO}=$ control and treatment on the week 0 , $\mathrm{K} 1 \mathrm{P} 1=$ control and treatment on the week 4, K2P2=control and treatment on the week 8, K3P3=control and treatment on the week 12. K=HE;400x, P=IHC_TGF- $\beta$. Black line $=200 \mu \mathrm{m}$

has been supposed to have an antifertility, and sex steroids have been implicated in the development and maintenance of Benign prostatic hyperplasia (BPH) and use of androgen reducing compounds, such as $5 \alpha$-reductase inhibitors which block the conversion of testosterone into dihydrotestosterone $[14,32,52]$. So that if eating the extract of M. charantia seeds will cause increasedĐestosterone levels to the highest culmination point and will eventuallyĐead to decrease in testosterone of body serum, testes and disturb of TGF- $\beta$ action in testis development $[54,59,104]$. Decreased testosterone in the body is replaced by DMPA. Hence, there is no decrease in libido $[5,28,93]$.

Sitosterol contained in bitter melon seed (M. charantia) can activate transformation growth factor- $\beta$ (TGF- $\beta$ ), causing apoptosis in spermatogenic cells and causing spermatozoa production to decrease and not even spermatozoa (azoospermia) (Fig. 3). That is, an increase in TGF- $\beta$ causes a decrease in spermatogenesis so that spermatozoa are not formed. According to Carson and Rittmaster, TGF- $\beta$ activity, which modulates apoptosis, is also influenced by dihydrotestosterone (DHT) $[143,144]$. More recently, the importance of DHT has been known to act as androgens and to be metabolized to $5 \alpha$-androstane- $3 \beta-17 \beta$-diol (3ßAdiol), androgens, which are a ligand for estrogen receptor [145-150].

\section{CONCLUSIONS}

Results showed that there was a significant effect $(p<0.05)$ of methanol extract of bitter melon seed to increase the TGF-beta expression in the testis tubulus seminiferous. Therefore, it was able to be candidate for herbal contraception.

\section{ACKNOWLEDGMENTS}

The authors gratefully acknowledge that the present research is supported by the Ministry of Research and Technology and Higher Education Republic of Indonesia (Kemenristekdikti). The support is under the number of research grant: 003/SP2H/LT/DRPM/IV/2017, date - May 20, 2017 (the $2^{\text {nd }}$ year of Competitive Grant).

\section{AUTHORS' CONTRIBUTION}

All the authors have contributed equally.

\section{CONFLICTS OF INTEREST}

The authors have declared that there are no conflicts of interest.

\section{REFERENCES}

1. Ilyas S, Salomo H, Nursal A. Quantity and quality of guinea pig (Cavia porcellus) spermatozoa after administration of methanol extract of bitter melon (Momordica charantia) seed and depot medroxy progesterone acetate (DMPA) Quantity and quality of guinea pig (Cavia porcellus). IOP Conf. Series: Earth Environ Sci 2018;130:1-7.

2. DHS (Bangladesh). Bangladesh and Family Planning: An overview. Bangladesh: DHS; 2011.p. 1-8

3. Ahmad N, Peng TN, Kamarul P, Kamarul F. Unfpa-icomp regional consultation. Fam Plan 2010; 2010:1-30.

4. Mansor M, Oo SS, Abdullah KL. Prevalence of family planning practices among women influenced by husband 's socio demography and decision making. J Sains Kesihat Malay 2015;3:19-25.

5. Costantino A, Gava G, Berra M, Meriggiola Maria C. Advances in male hormonal contraception. Indian J Med Res 2014;140 Suppl: S58-62.

6. Kanakis GA, Goulis DG. Male contraception: A clinically-oriented review. Hormones (Athens) 2015;14:598-614

7. MacQuarrie KL, Edmeades J, Steinhaus M, Head SK. Men and Contraception: Trends in Attitudes and Use. DHS Analytical Studies; 2015.

8. Rashmi T, Jhuma S, Bhattacharya S. Bitter melon: A bitter body with a sweet soul. Int J Res Ayurveda Pharm 2011;2:443-7.

9. Uddin I, NS H. Bio-active compounds of bitter melon genotypes (Momordica charantia L.) in relation to their physiological functions. Funct Foods Heal Dis 2011;1:61-74.

10. Bakare R, Magbagbeola O, Akinwande AI, Okunowo O. Nutritional and chemical evaluation of Momordica charantia. J Med Plants Res 2010;4:2189-93.

11. Daniel P, Supe U, Roymon MG. A review on phytochemical analysis of Momordica charantia. Int J Adv Pharm Biol Chem 2014:3:214-20.

12. Bakare RL, Magbagbeola OA, Akinwande AI, Okunowo OW, Green M. Antidiarrhoeal activity of aqueous leaf extract of Momordica charantia in rats. J Pharm Phyther 2011;3:1-7.

13. Mishra AK, Gautam A, Pal S, Mishra S, Rawat A, Maurya AK, et al. Innovare academic sciences effect of Momordica charantia fruits on streptozotocin-induced diabetes mellitus and its associated complications. Diabetic 2015;7:4-11.

14. Tumkiratiwong P, Ploypattarapinyo R, Pongchairerk U, Thong-Asa W. Reproductive toxicity of Momordica charantia ethanol seed extracts in male rats. Iran J Reprod Med 2014;12:695-704.

15. Tcheghebe OT, Timoléon M, Seukep AJ, Tatong FN. Ethnobotanical uses, phytochemical and pharmacological profiles, and cultural value of Momordica chlarantia Linn : An overview. Glob J Med Plant Res 2016;4:23-39.

16. Adewale OO, Oduyemi OI, Ayokunle O. Oral administration of leaf extracts of Momordica charantia affect reproductive hormones of adult female wistar rats. Asian Pac J Trop Biomed 2014;4:S521-4. 
17. Agarwal M, Kamal R. In vitro clonal propagation and phytochemical analysis of Momordica charantia. Linn. J Pharm Phytochem 2013;8192:2668735-5.

18. Alsultanee IR, Ewadh MJ, Mohammed MF. Novel natural anti gout medication extract from Momordica charantia. J Nat Sci Res 2014;4:16-24.

19. Ilyas S. Effect of methanolic Momordica charantia seed extract and depot medroxyprogesterone acetate (DMPA) to quantity and quality of rat sperm. Int J PharmTech Res 2014;6:1817-23.

20. Ilyas S, Lestari SW, Moeloek N, Asmarinah, Siregar NC. Induction of rat germ cell apoptosis by testosterone undecanoate and depot medroxyprogesterone acetate and correlation of apoptotic cells with sperm concentration. Acta Med Indones 2013;45:32-7.

21. Arianto A, Bangun H, Harahap U, Ilyas S. Eefect of alginate chitosan ratio on the swelling, mucoadhesive, and release of ranitidine from spherical matrices of alginate-chitosan. Int J Pharm Tech Res 2015;8:653-65.

22. Krishnaveni M, Mirunalini S. Amla-the role of ayurvedic therapeutic herb in cancer. Asian J Pharm Clin Res 2011;4:13-7.

23. Haque ME, Alam MB, Hossain MS. The efficacy of cucurbitane type triterpenoids, glycosides and phenolic compounds isolated from Momordica charantia: A review. Int J Phram Sci Res 2011;2:1135-46.

24. N N, Mohammed A, Shanbhag V, Ashfaque K, S AP. A comparative study of RIPASA score and ALVARADO score in the diagnosis of acute appendicitis. J Clin Diagn Res 2014;8:NC03-5.

25. Gu YQ, Tong JS, Ma DZ, Wang XH, Yuan D, Tang WH, et al. Male hormonal contraception: Effects of injections of testosterone undecanoate and depot medroxyprogesterone acetate at eight-week intervals in chinese men. J Clin Endocrinol Metab 2004;89:2254-62.

26. Pfizer Ltd. Depot-medroxyprogesterone acetate (DMPA -SC): Application for Inclusion in the WHO Essential Medicines List. UK: Sayana ${ }^{\circledR}$ Press; 2016. p. 1-56.

27. Hydrochloride B, Aid SC. Product Monograph; 2004. p. 1-19.

28. McLachlan RI. Effects of testosterone plus medroxyprogesterone acetate on semen quality, reproductive hormones, and germ cell populations in normal young men. J Clin Endocrinol Metab 2002;87:546-56

29. Ozgoli G, Sheikhan Z, Dolatian M, Simbar M, Bakhtyari M, Nasiri M, et al. Comparison of sexual dysfunction in women using depomedroxyprogesterone acetate (DMPA) and cyclofem. J Reprod Infertil 2015;16:102-8

30. Sahu RK, Jain A, Nayak S. Momordica Charantia Linn: A mini review. Int J Biomed Res 2011;2:579-87.

31. Meyer WJ $3^{\text {rd }}$, Cole C, Emory E. Depo provera treatment for sex offending behavior: An evaluation of outcome. Bull Am Acad Psychiatry Law 1992;20:249-59.

32. Date R, Date PM, Report TA, June PC. Safety Assessment of Dialkyl Sulfosuccinate Salts as Used in Cosmetics Status: Release Date: Panel Meeting Date : Tentative Amended Report for Public Comment; 2013.

33. Goulis DG, Polychronou P, Mikos T, Grimbizis G, Gerou S, Pavlidou V, et al. Serum inhibin-B and follicle stimulating hormone as predictors of the presence of sperm in testicular fine needle aspirate in men with azoospermia. Hormones (Athens) 2008;7:140-7.

34. Mansouri E, Asadi-Samani M, Kootiwesamkooti W. Anti-fertility effect of hydro-alcoholic extract of fennel (Foeniculum vulgare Mill) seed in male Wistar rats. J Vet Res 2016;60:357-63.

35. Sharma RK, Goyal AK. Effect of nano molar concentration of methyl parathion on goat testis. J Pharm Pharm Sci 2014;6:200-2.

36. Graeff FG, Junior HZ. The hypothalamic-pituitary-adrenal axis in anxiety and panic. Psychol Neurosci 2010;3:3-8.

37. Tojo C. Hypothalamic-pituitary-adrenal dependent diabetes axis in wbn/kob. Diabetes Mellitus 1996;43:233-9.

38. Ferrari E, Cravello L, Muzzoni B, Casarotti D, Paltro M, Solerte SB, et al. Age-related changes of the hypothalamic-pituitary-adrenal axis: Pathophysiological correlates. Eur J Endocrinol 2001;144:319-29.

39. Toorie AM, Cyr NE, Steger JS, Beckman R, Farah G, Nillni EA, et al. The nutrient and energy sensor sirt1 regulates the hypothalamicpituitary-adrenal (HPA) axis by altering the production of the prohormone convertase 2 (PC2) essential in the maturation of corticotropin-releasing hormone $(\mathrm{CRH})$ from its prohormone in male rats. J Biol Chem 2016;291:5844-59.

40. Leal AM, Moreira AC. Food and the circadian activity of the hypothalamic-pituitary-adrenal axis. Braz J Med Biol Res 1997;30:1391-405.

41. Rao R. Hypothalamic-pituitary-adrenal axis programming after recurrent hypoglycemia during development. J Clin Med $2015 ; 4: 1729-40$.
42. Zhou Y, Spangler R, Maggos CE, Wang XM, Han JS, Ho A, et al. Hypothalamic-pituitary-adrenal activity and pro-opiomelanocortin mRNA levels in the hypothalamus and pituitary of the rat are differentially modulated by acute intermittent morphine with or without water restriction stress. J Endocrinol 1999;163:261-7.

43. Bachmann CG, Linthorst AC, Holsboer F, Reul JM. Effect of chronic administration of selective glucocorticoid receptor antagonists on the rat hypothalamic-pituitary-adrenocortical axis. Neuropsychopharmacology 2003;28:1056-67.

44. Kelberman D, Dattani MT. Hypothalamic and pituitary development: Novel insights into the aetiology. Eur J Endocrinol 2007;157 Suppl 1:S3-14.

45. Schmidt MV, Liebl C, Sterlemann V, Ganea K, Hartmann J, Harbich D, et al. Neuropeptide Y mediates the initial hypothalamicpituitary-adrenal response to maternal separation in the neonatal mouse. J Endocrinol 2008; 197:421-7.

46. Coventry TL, Jessop DS, Finn DP, Crabb MD, Kinoshita H, Harbuz MS, et al. Endomorphins and activation of the hypothalamopituitary-adrenal axis. J Endocrinol 2001;169:185-93.

47. Beishuizen A, Thijs LG. Endotoxin and the hypothalamo-pituitaryadrenal (HPA) axis. J Endotoxin Res 2003;9:3-24.

48. Anbu J, Nithya S, Kannadhasan R, Kishore G, Anjana A, Suganya S. Antioxidant and protective effect of aqueous extract of Ichnocarpus frutescens and Cyperus rotundus against cisplatin induced testicular toxicity in rodents. Int J Pharm Pharm Sci 2012;4:1-5.

49. Ogbuewu IP, Unamba-Oparah IC, Odoemenam VU, Etuk IF, Okoli IC. The potentiality of medicinal plants as the source of new contraceptive principles in males. N Am J Med Sci 2011;3:255-63.

50. Oliveira JS, Silva AA, Silva VA Junior. Phytotherapy in reducing glycemic index and testicular oxidative stress resulting from induced diabetes: A review. Braz J Biol 2016;0:0.

51. Munell F, Suárez-Quian CA, Selva DM, Tirado OM, Reventós J. Androgen-binding protein and reproduction: Where do we stand? J Androl 2002;23:598-609.

52. Nicholson TM, Ricke WA. Androgens and estrogens in benign prostatic hyperplasia: Past, present and future. Differentiation 2011;82:184-99.

53. Ma Y, Yang HZ, Xu LM, Huang YR, Dai HL, Kang XN, et al. Testosterone regulates the autophagic clearance of androgen binding protein in rat sertoli cells. Sci Rep 2015;5:8894

54. Morris ID, Bardin CW, Musto NA, Thau R, Gunsalus GL. Androgen binding protein in serum, testis and epididymis following treatment with the leydig cell cytotoxic agent, ethylene dimethanesulphonate. Int J Androl 1988;11:153-63.

55. Sinha RA, Khare P, Rai A, Maurya SK, Pathak A, Mohan V, et al. Anti-apoptotic role of omega-3-fatty acids in developing brain: Perinatal hypothyroid rat cerebellum as apoptotic model. Int J Dev Neurosci 2009;27:377-83.

56. Peper JS, van den Heuvel MP, Mandl RC, Hulshoff Pol HE, van Honk J. Sex steroids and connectivity in the human brain: A review of neuroimaging studies. Psychoneuroendocrinology 2011;36:1101-13.

57. Zuo Q, Jin K, Zhang Y, Song J, Li B. Dynamic expression and regulatory mechanism of TGF- $\beta$ signaling in chicken embryonic stem cells differentiating into spermatogonial stem cells. Biosci Rep 2017;37: pii: BSR20170179.

58. Memon MA, Anway MD, Covert TR, Uzumcu M, Skinner MK. Transforming growth factor beta (TGFbeta1, TGFbeta2 and TGFbeta3) null-mutant phenotypes in embryonic gonadal development. Mol Cell Endocrinol 2008;294:70-80.

59. Itman C, Mendis S, Barakat B, Loveland KL. All in the family: TGF-beta family action in testis development. Reproduction 2006;132:233-46

60. Park KS. Tgf-beta family signaling in embryonic stem cells. Int J Stem Cells 2011;4:18-23

61. Yang Y, Feng Y, Feng X, Liao S, Wang X, Gan H, et al. BMP4 cooperates with retinoic acid to induce the expression of differentiation markers in cultured mouse spermatogonia. Stem Cells Int 2016;2016:9536192.

62. Richards AJ, Enders GC, Resnick JL. Activin and TGFbeta limit murine primordial germ cell proliferation. Dev Biol 1999;207:470-5.

63. Chuva de Sousa Lopes SM, van den Driesche S, Carvalho RL, Larsson J, Eggen B, Surani MA, et al. Altered primordial germ cell migration in the absence of transforming growth factor beta signaling via ALK5. Dev Biol 2005;284:194-203.

64. Publication A, Rep M. "Page 1 of. Reproduction; 2009. p. 1-27.

65. Wang B, Harrison W, Overbeek PA, Zheng H. Transposon mutagenesis with coat color genotyping identifies an essential role for skor2 in sonic hedgehog signaling and cerebellum development. Development 2011;138:4487-97. 
66. Henderson GI, Chen J, Schenker S. Ethanol, oxidative stress, reactive aldehydes, and the fetus. Front Biosc1999;1972:541-50.

67. Ad K, Mohite R, Aggrawal AS, Ur S. Hepatoprotective medicinal plants of ayurveda - a review. Asian J Pharm Clinical Res 2011;4:1-8.

68. Singh AB, Kaushal V, Megyesi JK, Shah SV, Kaushal GP. Cloning and expression of rat caspase- 6 and its localization in renal ischemia/ reperfusion injury. Kidney Int 2002;62:106-15.

69. Imosemi OI. The role of antioxidants in cerebellar development. A review of literature. Int J Morphol 2013;31:203-10.

70. Dean SL, Mccarthy MM. NIH public access. Energy 2009;7:38-47.

71. World Health Organization (WHO). WHO Traditional Medicine Strategy 2002-2005. Geneva: World Health Organization; 2002. p. 1-74.

72. Bregano LC. Expression of pro-and-anti-apoptotic antigens in the cerebellum of dogs naturally infected with canine distemper virus. Medicina (B. Aires) 2010;3:80-5.

73. Ghoumari AM, Wehrle R, De Zeeuw CI, Sotelo C, Dusart I. Inhibition of protein kinase $\mathrm{C}$ prevents purkinje cell death but does not affect axonal regeneration. J Neurosci 2002;22:3531-42.

74. Taranukhin AG, Taranukhina EY, Saransaari P, Podkletnova IM, Pelto-Huikko M, Oja SS, et al. Neuroprotection by taurine in ethanolinduced apoptosis in the developing cerebellum. J Biomed Sci 2010;17 Suppl 1:S12.

75. Peng J, Wu Z, Wu Y, Hsu M, Stevenson FF, Boonplueang R, et al. Inhibition of caspases protects cerebellar granule cells of the weaver mouse from apoptosis and improves behavioral phenotype. J Biol Chem 2002;277:44285-91.

76. Paneerchelvan S, Lai1 HY, Kailasapathy K. Antioxidant, antibacterial and tyrosinase inhibiting activities of extracts from Myristica fragrans Houtt. Eur J Med Plants 2015;8:39-49.

77. Lossi L, Gambino G. Apoptosis of the cerebellar neurons. Histol Histopathol 2008;23:367-80.

78. Lotta LT, Conrad K, Cory-Slechta D, Schor NF. Cerebellar purkinje cell p 75 neurotrophin receptor and autistic behavior. Transl Psychiatry 2014;4:e416.

79. Sharma RK, Goyal AK. Innovare academic sciences agro-pesticides and andrology. Int J Pharm Pharm Sci 2014;6:200-2.

80. Yuan J, Lipinski M, Degterev A. Diversity in the mechanisms of neuronal cell death. Neuron 2003;40:401-13.

81. Kumar A, LaVoie HA, DiPette DJ, Singh US. Ethanol neurotoxicity in the developing cerebellum: Underlying mechanisms and implications. Brain Sci 2013;3:941-63.

82. Kitagishi Y, Minami A, Nakanishi A, Ogura Y, Matsuda S. Neuron membrane trafficking and protein kinases involved in autism and ADHD. Int J Mol Sci 2015;16:3095-115.

83. Hap MU, Nasution MP, Ilyas S. Cytotoxic activity, proliferation inhibition and apoptosis induction of Rhaphidophora pinnata (L.F.) schott chloroform fraction to MCF-7 cell line. Int J Pharm Tech Res 2014;6:1327-33.

84. Oliveira SA, Chuffa LG, Fioruci-Fontanelli BA, Lizarte Neto FS, Novais PC, Tirapelli LF, et al. Apoptosis of purkinje and granular cells of the cerebellum following chronic ethanol intake. Cerebellum 2014;13:728-38

85. Adeyi AO, Jinadu AM, Arojojoye AO, Alao OO, Ighodaro OM, Adeyi OE. In vivo and in vitro antibacterial activities of Momordica charantia on Salmonella typhi and its effect on liver function in typhoid-infected rats. J Pharmacogn Phyther 2011;5:183-8.

86. Akosman MS, Gocmen-Mas N, Karabekir HS. Estimation of purkinje cell quantification and volumetry in the cerebellum using a stereological technique. Folia Morphol (Warsz) 2011;70:240-4

87. Harahap MU, Nasution MP, Ilyas S. The activity of Rhaphidophora pinnta Lf. Schott leaf on MCF-7 cell line. Adv Biol Chem 2013;3:397-402.

88. BJ D, AO O. Histological alteration of the cerebellum of adult male wistar rat treated with the grapefruit extract (Citrus paradisi). Anat Physiol 2012;4:2-4.

89. Hadisahputra S, Ilyas S. Combinational effects of ethylacetate extract of Zanthoxyluma canthopodium DC. With doxorubicinon MCF7breast cancer cells. Int J Pharm Tech Res 2015;7:651-3.

90. Duraisami R, Mohite VA, Kasbe AJ. Anti stress, adaptogenic activity of standardized dried fruit extract of Aegle marmelos against diverse stressors. Asian J Pharm Clin Res 2010;3:1-3.

91. Pathak A, Shenoy S, Kiran S, Avinash A, Nayak D. Effect of ethanolic extract of Cyanotis cristata Leaves applied topically on wound healing in wistar rats. Asian J Pharm Clin Res 2017;10:63.

92. Satria D, Nasution MP, Illyas S. Cytotoxcicity effect of sea horse (Hippocampus trimaculatus Leach.) extract and fractions on MCF-7 cell line. Int J Pharm Tech Res 2014;6:212-6.

93. Hasibuan R, Ilyas S, Hanum S. Effect of leaf extract haramonting (Rhodomyrtus tomentosa) to lower blood sugar levels in mice induced by alloxan. Int J Pharm Tech Res 2015;8:284-91.

94. Leake R, Barnes D, Pinder S, Ellis I, Anderson L, Anderson T, et al. Immunohistochemical detection of steroid receptors in breast cancer: A working protocol. UK receptor group, UK NEQAS, the scottish breast cancer pathology group, and the receptor and biomarker study group of the EORTC. J Clin Pathol 2000;53:634-5.

95. Bercu BB, Jackson IM. Response of adult male rats to LH-RH after neonatal immunization with antiserum to LH-RH. J Reprod Fert 1980;59:501-7.

96. Sanchez-Criado JE, Galiot F, Bellido C, Gonzalez D, Tebar M. Hypothalamus-pituitary-ovarian axis in cyclic rats lacking progesterone actions. Biol Reprod 1993;48:916-925.

97. Beckett JL, Sakurai H, Adams BM, Adams TE. Moderate and severe nutrient restriction has divergent effects on gonadotroph function in orchidectomized sheep. Biol Reprod 1997;57:415-9.

98. Yu WH, Karanth S, Walczewska A, Sower SA, McCann SM. A hypothalamic follicle-stimulating hormone-releasing decapeptide in the rat. Proc Natl Acad Sci U S A 1997;94:9499-503.

99. Schally AV, Kastin AJ, Arimura A. Hypothalamic follicle-stimulating hormone (FSH) and luteinizing hormone (LH)-regulating hormone: Structure, physiology, and clinical studies. Fertil Steril 1971;22:703-21.

100. Ahmadi R, Gohari A, Hooshmand M. The effect of noise stress on serum levels of LH, FSH and testosterone in male rats. Feyz 2015;19:24-9.

101. Calogero AE, Burrello N, Ossino AM, Polosa P, D’Agata R. Activin-A stimulates hypothalamic gonadotropin-releasing hormone release by the explanted male rat hypothalamus: Interaction with inhibin and androgens. J Endocrinol 1998;156:269-74.

102. Dhillo WS, Chaudhri OB, Patterson M, Thompson EL, Murphy KG, Badman MK, et al. Kisspeptin-54 stimulates the hypothalamicpituitary gonadal axis in human males. J Clin Endocrinol Metab 2005;90:6609-15.

103. Tehrani FR, Noroozzadeh M, Zahediasl S, Piryaei A, Azizi F. Introducing a rat model of prenatal androgen-induced polycystic ovary syndrome in adulthood. Exp Physiol 2014;99:792-801.

104. Rebourcet D, O'Shaughnessy PJ, Monteiro A, Milne L, Cruickshanks L, Jeffrey N, et al. Sertoli cells maintain leydig cell number and peritubular myoid cell activity in the adult mouse testis. PLoS One 2014;9:e105687.

105. Rebourcet D, Darbey A, Monteiro A, Soffientini U, Tsai YT, Handel I, et al. Sertoli cell number defines and predicts germ and leydig cell population sizes in the adult mouse testis. Endocrinology 2017; 158:2955-69

106. Tanaka T, Kanatsu-Shinohara M, Lei Z, Rao CV, Shinohara T. The luteinizing hormone-testosterone pathway regulates mouse spermatogonial stem cell self-renewal by suppressing WNT5A expression in sertoli cells. Stem Cell Reports 2016;7:279-91.

107. Allan CM, Garcia A, Spaliviero J, Zhang FP, Jimenez M, Huhtaniemi I, et al. Complete sertoli cell proliferation induced by follicle-stimulating hormone (FSH) independently of luteinizing hormone activity: Evidence from genetic models of isolated FSH action. Endocrinology 2004; 145:1587-93

108. Abel MH, Baker PJ, Charlton HM, Monteiro A, Verhoeven G, De Gendt K, et al. Spermatogenesis and sertoli cell activity in mice lacking sertoli cell receptors for follicle-stimulating hormone and androgen. Endocrinology 2008;149:3279-85.

109. Walker WH, Cheng J. FSH and testosterone signaling in sertoli cells. Reproduction 2005;130:15-28.

110. Iliadou PK, Tsametis C, Kaprara A, Papadimas I, Goulis DG. The sertoli cell: Novel clinical potentiality. Hormones (Athens) 2015;14:504-14.

111. Ilkhanizadeh B, Taghizadieh M, Mahzad-sadaghiani M. Bilateral leydig cell tumor and male infertility: A case report. Iran J Reprod Med 2015;3:47-9.

112. Setchell BP, Pakarinen P, Huhtaniemi I. How much LH do the leydig cells see? J Endocrinol 2002;175:375-82.

113. Obiorah IE, Kyrillos A, Ozdemirli M. Case report synchronous leydig cell tumor and seminoma in the ipsilateral testis. Case Reports Urol 2018;2018(c):1-5.

114. Manna PR, Jo Y, Stocco DM. Regulation of leydig cell steroidogenesis by extracellular signal-regulated kinase $1 / 2$ : Role of protein kinase $\mathrm{A}$ and protein kinase C signaling. J Endocrinol 2007;193:53-63.

115. Chung E, Yang Y, Kang H, Choi K, Jun J. Ultrastructure of germ cells and the functions of leydig cells and sertoli cells associated with 
spermatogenesis in. Zool Stud 2010;49:39-50.

116. Hibi H, Yamashita K, Sumitomo M, Asada Y. Leydig cell tumor of the testis, presenting with azoospermia. Reprod Med Biol 2017;16:392-5.

117. Opałka M, Kamińska B, Ciereszko R, Dusza L. Genistein affects testosterone secretion by leydig cells in roosters (Gallus gallus domesticus). Reprod Biol 2004;4:185-93.

118. To K, Oe Y, Ao O. Effect of Carica papaya bark extract on oxidative stress parameters in testes of male albino rats. Int J Appl Res Nat Prod 2012;4:1-6.

119. Okoro VM, Mbajiorgu CA, Mbajiorgu EF. Semen quality characteristics of koekoek breeder cocks influenced by supplemental inclusion levels of onion and garlic mixture at 35-41 weeks of age. Rev Bras Zootec 2016;45:433-40.

120. Yama OE, Duru FI, Oremosu AA, Noronha CC, Okanlawon A. Suppressive effects of Momordica charantia on pituitary-testicular axis and sperm production in male Sprague-Dawley rats. Int J Med Med Sci 2011;3:353-9.

121. Eboetse YO, Ikechukwu DF, Olugbenga OA, Ayodele OA, Caramel NC. Histomorphological alterations in the prostate gland and epithelium of seminiferous tubule of sprague-dawley rats treated with methanolic extract of Momordica charantia seeds. Iran J Med Sci 2011;36:266-72.

122. Eilam D, Golani I. Home base behavior in amphetamine-treated tame wild rats (Rattus norvegicus). Iran J Med Sci 1990;36:161-70.

123. Setiawan A, Sagi M, Asmara W. Analisis kuantitatif sel purkinje cerebellum mencit (Mus musculus L) setelah induksi ochratoksin a selama periode organogenesis quantitative analysis of the purkinje cell in mice cerebellum after induction of ochratoxin a during organogenesis period. J Biol Papua 2011;16:3.

124. Ju YH, Clausen LM, Allred KF, Almada AL, Helferich WG. Betasitosterol, beta-sitosterol glucoside, and a mixture of beta-sitosterol and beta-sitosterol glucoside modulate the growth of estrogenresponsive breast cancer cells in vitro and in ovariectomized athymic mice. J Nutr 2004;134:1145-51.

125. Arora M, Kalia AN, Mishra R, Siddqui AA. Isolation and characterization of stigmasterol and $\beta$-sitosterol-D-glycoside from ethanolic extract of the stems of Salvadora persica Linn. Int J Pharm Pharm Sci 2013;5 Suppl.1:245-9.

126. Peshin T, Kar H. Isolation and characterization of $\beta$-Sitosterol-3-O$\beta$-D-glucoside from the extract of the flowers of Viola odorata. Br J Pharm Res 2017;16:1-8.

127. Saeidnia S. The story of beta-sitosterol- a review. Eur J Med Plants 2014;4:590-609.

128. Hossain MS, Khan NM. Scopoletin and $\beta$-sitosterol glucoside from roots of Ipomoea digitata. J Pharm Phytochem 2015;4:5-7.

129. Prakash O, Kumar A, Kumar P, Ajeet A. Anticancer potential of plants and natural products: A review. Am J Pharm Sci 2013;1:104-15.

130. Jawad A, Balayeshwanth RV, Rami A, Waleed R, Hatem S, Nathan WL. The influence of extraction solvents on the anticancer activities of Palestinian medicinal plants. J Med Plants Res 2014;8:408-15.

131. Manglani N, Vaishnava S, Dhamodaran P, Sawarkar H. In vitro and in vivo anti-cancer activity of leaf extract of Barleria grandiflora. Int J Pharm Pharm Sci 2014;6:14-6.

132. Ghagane SC, Puranik SI, Kumbar VM, Nerli RB, Jalalpure SS, Hiremath $\mathrm{MB}$, et al. In vitro antioxidant and anticancer activity of Leea indica leaf extracts on human prostate cancer cell lines. Integr Med Res 2017;6:79-87.

133. Solowey E, Lichtenstein M, Sallon S, Paavilainen H, Solowey E,
Lorberboum-Galski H. Evaluating medicinal plants for anticancer activity. Sci World J 2014;2014:12.

134. Arianto A. Antiulcer effect of gastroretentive spherical matrices of alginate-chitosan containing ranitidine HCL. Int J Pharm Tech Res 2016;9:342-52

135. Ashour AA, Raafat D, El-Gowelli HM, El-Kamel AH. Green synthesis of silver nanoparticles using cranberry powder aqueous extract: Characterization and antimicrobial properties. Int $\mathrm{J}$ Nanomedicine 2015;10:7207-21.

136. Sakthivel KM, Guruvayoorappan C. Acacia ferruginea inhibits inflammation by regulating inflammatory iNOS and COX-2. J Immunotoxicol 2016;13:127-35.

137. Meshram GG, Kumar A, Rizvi W, Tripathi CD, Khan RA. Evaluation of the anti-inflammatory activity of the aqueous and ethanolic extracts of the leaves of Albizzia lebbeck in rats. J Tradit Complement Med 2016;6:172-5.

138. Tatiya A, Saluja A, Kalaskar M, Surana S, Patil P. Phytochemical characterization and anti-inflammatory activity of Bridelia retusa bark spreng. In acute and chronic inflammatory conditions: A possible mechanism of action. Ejpmr 2017;4:686-96.

139. Tanaka K, Ohgo Y, Katayanagi Y, Yasui K, Hiramoto S, Ikemoto H, et al. Anti-inflammatory effects of green soybean extract irradiated with visible light. Sci Rep 2014;4:4732.

140. Sarkhel S. Evaluation of the anti-inflammatory activities of Quillaja saponaria mol. Saponin extract in mice. Toxicol Rep 2016;3:1-3.

141. Mohammadi-Motlagh HR, Mostafaie A, Mansouri K. Anticancer and anti-inflammatory activities of shallot (Allium ascalonicum) extract. Arch Med Sci 2011;7:38-44.

142. de Oliveira RG, Mahon CP, Ascêncio PG, Ascêncio SD, Balogun SO, de Oliveira Martins DT, et al. Evaluation of anti-inflammatory activity of hydroethanolic extract of dilodendron bipinnatum radlk. J Ethnopharmacol 2014;155:387-95.

143. Weng Y, Xie F, Xu L, Zagorevski D, Spink DC, Ding X, et al. Analysis of testosterone and dihydrotestosterone in mouse tissues by liquid chromatography-electrospray ionization-tandem mass spectrometry. Anal Biochem 2010;402:121-8.

144. Lee PW, Swerdloff RS. NIH public access. Biosystems 2009;73:1345-52

145. Seidlova-Wuttke D, Hesse O, Jarry H, Christoffel V, Spengler B, Becker T, et al. Evidence for selective estrogen receptor modulator activity in a black cohosh (Cimicifuga racemosa) extract: Comparison with estradiol-17beta. Eur J Endocrinol 2003;149:351-62.

146. Lee YM, Kim JB, Bae JH, Lee JS, Kim PS, Jang HH, et al. Estrogenlike activity of aqueous extract from Agrimonia pilosa ledeb. In MCF7 cells. BMC Complement Altern Med 2012;12:260.

147. Miyuki K, Nobuhiro S, Daimei S, Hidehiko S, Yoshimichi M, Kunimasa A, et al. Sex differences in the serum level of endogenous ligands for estrogen receptor $\beta$ in the elderly population. Scie Rep 2016;6:25878.

148. Rich RL, Hoth LR, Geoghegan KF, Brown TA, LeMotte PK, Simons SP, et al. Kinetic analysis of estrogen receptor/ligand interactions. Proc Natl Acad Sci U S A 2002;99:8562-7.

149. Joshia SC, Sharmaa A, Chaturvedib A. Antifertility potential of some medicinal plants in males: An overview. Int J Pharm Pharm Sci 2011;3:204-17.

150. Pakhira BP, Jana K, Ghosh A, Ghosh D. Antitesticular activity of hydro-methanol extract of Cuminum cyminum in adult rat: A dose dependent study. Int J Pharm Pharm Sci 2015;7:285-91. 